\title{
Proximate Composition and Amino Acids of Four Species of Pine Caterpillars (Lepidoptera: Lasiocampidae)
}

\author{
Jian-Zhong He, Zhong-He Zhang* \\ Research Institute of Resource Insects, Chinese Academy of Forestry, Kunming, China \\ Email address: \\ hjzhkm@163.com (Jian-Zhong He),Zhzhang.caf@163.com (Zhong-He Zhang) \\ ${ }^{*}$ Corresponding author
}

To cite this article:

Jian-Zhong He, Zhong-He Zhang. Proximate Composition and Amino Acids of Four Species of Pine Caterpillars (Lepidoptera: Lasiocampidae). Agriculture, Forestry and Fisheries. Vol. 6, No. 2, 2017, pp. 55-58. doi: 10.11648/j.aff.20170602.11

Received: February 27, 2017; Accepted: March 10, 2017; Published: March 25, 2017

\begin{abstract}
The objectives of the study were to analyze the nutritional composition of some species of pine caterpillars and to encourage utilization of these forest insect pests, therefore, the study constituted part of IPM (Integrated Pest Management) for these forest pests in China. The results showed that the crude protein (CP) content of the pupae of 4 species ranged from $53.55 \%$ to $61.26 \%$. The CP content of the adults of 2 species was $58.04 \%$ and $68.30 \%$ respectively. The fat and the energy content ranged from 19.75 to $26.46 \%$ and from 406 to $473 \mathrm{kcal}$ per $100 \mathrm{~g}$ for the pupae; 6.56 to $24.63 \%$ and 327 to $454 \mathrm{kcal}$ per $100 \mathrm{~g}$ for the adults respectively. As compared with the essential amino acids according to WHO/FAO/UNU pattern, some of the essential amino acids for human adult nutrition are found to be higher than the levels as recommended by WHO/FAO/UNU.
\end{abstract}

Keywords: Pine Caterpillars, Protein, Amino Acids, Composition, Forest Pests

\section{Introduction}

Insects are intentionally consumed as food by people worldwide $[13,21]$ at all stages of development as eggs, larvae, pupae and adults, but most of them in immature stages $[13,14,16,18]$. Insects contain a high amount of crude protein, their nutritional value compares very favourably with other foods consumed by humans [17, 22]. Edible insects constitute a very important food source in many developing countries. Studies have shown that they are good sources of high quality proteins, fats and minerals [1, 3, 6, 8, 10, 19]. For many species of insects, protein quality, as evaluated by amino acid profiles, compared favorably to those recommended for nutritional purposes by FAO/OMS [18]. Mass rearing of insects as alternative protein sources had been advocated by many workers [7, 18].

It is evident that there is a great diversity and widespread use of insects as human food [9]. The encouragement of entomophagy in many rural societies, particularly those with a history of insect use may help diversify peoples' diets. However, insects as a major animal group possess enormous biodiversity and form a colossal biomass in nature are generally wasted $[11,18]$, and enormous quantities of toxic substances are used to kill them. Indeed, many insect pests are exterminated at a significant price while they are perfectly edible and could be used as a food source [18].

It is well known that pine caterpillars are the most destructive forest pests in China, devastating vast areas of pine forests and causing a loss worth of billions of Yuan and adverse effect on the environment and forest ecological system each year. The damage caused by the pests is called as "non-smoking fire disaster" [4, 12, 15, 27, 29]. The Chinese government used to and still now spends millions of Yuan on controlling and preventing the infestation of these insects, mainly by applying insecticides. Though the chemical products can temporarily put the pests under control, they will become even more rampant and serious the next year, and the use of chemical products adds to damage and pollution of the environment and forest system.

Recently, we found that some ethnic groups in a lot of areas in Yunnan use pine caterpillars (mostly in form of pupae) for several reasons. For example, some family of the Hani group in Mojang harvest hundreds of kilograms of the insect pupae as food, feed, and for medicinal purposes. On the basis of this ethnoentomological knowledge and practice, one question that was raised: Could the mass-harvesting of the pine caterpillar be combined with pest control? In fact, many researchers consider 
that some pest insects might be used as food as a method of IPM (Integrated Pest Management). DeFoliart (1993) believed that collection of some pests as food might serve as a form of biological control. Such a practice might result in the reduction of pesticides as well as creating new economic opportunities for indigenous people [6]. Ramos-Elorduy (1997) and Gullan and Cranston (2004) expressed similar idea that if mass harvesting of pest insects are incorporated into pest control programs, the use of pesticides can be reduced $[11,18]$.

It is important to know the nutritional value of the pine caterpillars consumed by local people in order to encourage local people harvest pine caterpillars as food. The nutritional value of food largely depends on the quality of the protein content. This in turn, is determined to a great extent, by the amino acid composition and protein digestibility [14]. In this paper, proximate analyses and amino acid profiles are dealt with of four species of pine caterpillars.: Dendrolimus Houi Lajonquiere; D. kikuchii Mats; D. punctatus wenshanensis Tsai et Liu; D. punctatus techangensis Tsai et Li.

\section{Material and Methods}

\subsection{Sampling}

The insects of Dendrolimus Houi Lajonquiere; D. kikuchii Mats; D. punctatus wenshanensis Tsai et Liu; D. punctatus techangensis Tsai et $L i$, were collected in different counties of Yunnan, China. All the pupae that were harvested is in the mid-pupal stage. The adults (moths) were harvested when they emerged in large quantities. They were placed in containers with dry ice and were transferred to Kunming Institute of Zoology, Chinese Academy of Science. The samples were oven dried at $60^{\circ} \mathrm{C}$, ground and reduced to powder using a 20-mesh screen.

\subsection{Biochemical Analysis}

Amino acid content was determined by high performance liquid chromatography (HPLC). About $10 \mathrm{mg}$ of the sample was hydrolysed with $\mathrm{HCL}$ at $110^{\circ} \mathrm{C}$ for $24 \mathrm{~h}$. After deacidification it was calibrated and then $20 \mu 1$ was injected into HPLC column. The quantification of the amino acids were determined by $\mathrm{LKB}=440$ amino acid analyzer equipped with a $\mathrm{LKB}=2220$ data processor. Both cystine and tryptophan were not determined. The crude protein content was determined by the Kjeldahl method (Huang Weikun 1989). Chitin was determined by the cold hydrochloric acid procedure. Total lipids, glycogen and ash were performed using procedures according to the Association of Official Analytical Chemists [2]. For the analysis of the lipids, a capillary gas chromatography ( Model Hitachi GC-9A equipped with a C-R3A data processor) was used. Approximately $3.97 \mathrm{~g}$ of the sample was weighed and extracted with petroleum ether, the resulting oil ester $(1.19 \mathrm{~g})$ was sonificated and treated with methyl ester. $0.15 \mu \mathrm{l}$ of the sample was injected into a GC capillary column (FFAP) with a column temperature $200^{\circ} \mathrm{C}$, injector temperature $230^{\circ} \mathrm{C}$ and $\mathrm{N}_{2}$ as carrier gas.

\section{Results}

\subsection{Composition of the Pupae and Adults of Pine Caterpillars}

The results of the proximate composition of the pupae and adults of 4 species pine caterpillars were shown in Table 1. For comparative purpose, the data listed in Table 1 was calculated on a dry weight $(\%)$ basis.

Table 1. Proximate composition of pupae and adults of four caterpillars (\%dry weight).

\begin{tabular}{|c|c|c|c|c|c|c|}
\hline \multirow{2}{*}{ Composition \% } & \multicolumn{2}{|c|}{ D. Houi } & \multicolumn{2}{|c|}{ D. punctatus techangensis } & \multirow{2}{*}{$\begin{array}{l}\text { D. punctatus wenshanensis } \\
\text { Pupae }\end{array}$} & \multirow{2}{*}{$\begin{array}{l}\text { D. kikuchii } \\
\text { Pupae } \\
\end{array}$} \\
\hline & Pupae & Adults & Pupae & Adults & & \\
\hline Protein & 58.15 & 68.30 & 61.11 & 58.04 & 61.26 & 53.55 \\
\hline Fat & 22.42 & 6.56 & 21.82 & 24.63 & 19.75 & 26.46 \\
\hline Glycogen & 6.82 & 1.51 & 0.65 & 0.43 & 9.70 & 0.61 \\
\hline Chitin & 7.47 & 17.83 & 9.99 & 9.85 & 6.49 & 11.79 \\
\hline Ash & 4.98 & 2.95 & 3.47 & 3.21 & 2.75 & 2.99 \\
\hline Calorific value $(\mathrm{kcal} / 100 \mathrm{~g})$ & 406 & 327 & 442 & 454 & 473 & 452 \\
\hline
\end{tabular}

The results showed that the crude protein content of the pupae ranged from $53.55 \%$ to $61.26 \%$. These results are similar to the pupae of five species as reported by Ramos-Elorduy et al. (1984) [18], which are 53.32\% in Liometopum apiculatum, $57.93 \%$ in Polistes major, $57.75 \%$ in Polistes instabilis, $61.54 \%$ in Musca domestica and $71.60 \%$ in Eucheria socialis. Similar findings were also obtained for protein content of $52.77 \%, 55.01 \%$ respectively for the pupae of silkworm, Antheraea permyi and Herse convolvuli, in China as reported by Yang Ti et al. (1993) [5, 28, 30]. The protein content of the adults of 2 species, D. punctatus techangensis and D. Houi, was $58.04 \%$ and $68.30 \%$ respectively, which was consistent with the results of $65.39 \%$ found in the adults of Pachilis gigas and 60.22\% in Ephydra hians as reported by Ramos-Elorduy (1984) [18].
Though insects vary widely in fat content and also in the caloric content, the fat content levels of pine caterpillars agree with some insects as reported by other authors from other parts of the world. The fat and the energy content of pine caterpillars ranged from $19.75 \%$ to $26.46 \%$ and from 406 to $473 \mathrm{kcal}$ per $100 \mathrm{~g}$ for the pupae, $6.56 \%$ to $24.63 \%$ and 327 to $454 \mathrm{kcal}$ per $100 \mathrm{~g}$ for the adults respectively. Ramos-Elorduy (1997) reported that the highest fat content was $77.00 \%$ in the larvae of Phastus triangularis, an edible insects form Mexico, and its caloric content ranged from 293 to $685 \mathrm{kcal}$ per $100 \mathrm{~g}$ [18]. According to the statistical data of edible insects from 32 families of 8 orders in Mexico, the average fat and caloric content were $27.4 \%$ and $475 \mathrm{kcal}$ per $100 \mathrm{~g}$ respectively [23]. 


\subsection{Amino Acids of Pupae and Adults of Pine Caterpillars}

The nutritional value of food largely depends on the quality of the protein it contains. However, this in turn is determined to a great extent, by the amino acid composition. Amino acids of the 4 species caterpillars are shown in Table 2.

Table 2. Amino acids (mg/100g protein) of pupae and adults of four pine caterpillars.

\begin{tabular}{|c|c|c|c|c|c|c|}
\hline \multirow{2}{*}{ Amino acids } & \multicolumn{2}{|c|}{ D. Houi } & \multicolumn{2}{|c|}{ D. punctatus tehchangensis } & \multirow{2}{*}{$\begin{array}{l}\text { D. punctatus winshanens } \\
\text { Pupae }\end{array}$} & \multirow{2}{*}{$\begin{array}{l}\text { D. kikuchii } \\
\text { Pupae }\end{array}$} \\
\hline & Pupae & Adults & Pupae & Adults & & \\
\hline Aspartic acid & 55.61 & 61.13 & 67.54 & 72.37 & 64.54 & 90.30 \\
\hline Threonine * & 30.34 & 31.56 & 34.71 & 35.73 & 31.74 & 41.17 \\
\hline Serine & 30.52 & 40.20 & 36.09 & 38.26 & 31.56 & 42.60 \\
\hline Glutamic acid & 100.69 & 106.98 & 122.36 & 112.43 & 109.22 & 104.16 \\
\hline Proline & 26.99 & 32.39 & 36.78 & 39.70 & 31.90 & 107.01 \\
\hline Glycine & 29.41 & 58.64 & 34.37 & 34.83 & 35.11 & 49.32 \\
\hline Valine * & 35.73 & 55.48 & 40.38 & 41.15 & 32.30 & 66.65 \\
\hline Methionine * & 26.43 & 13.12 & 39.87 & 24.91 & 33.33 & 18.34 \\
\hline Isoleucine* & 32.01 & 43.34 & 39.53 & 35.55 & 30.85 & 43.00 \\
\hline Leucine * & 38.34 & 59.14 & 52.41 & 55.22 & 42.02 & 58.30 \\
\hline Tyrosine* & 35.18 & 49.50 & 44.17 & 44.94 & 34.04 & 43.00 \\
\hline Phenylalanine * & 30.15 & 10.13 & 33.68 & 32.67 & 32.80 & 42.60 \\
\hline Histidine* & 19.73 & 29.57 & 22.51 & 21.66 & 20.21 & 46.47 \\
\hline Arginine & 29.41 & 41.86 & 36.95 & 43.49 & 34.93 & 0 \\
\hline Tryptophan* & NA & NA & NA & NA & NA & NA \\
\hline Total & 619.55 & 765.1 & 726.24 & 737.59 & 666.14 & 798.99 \\
\hline
\end{tabular}

NA: not attempted;*:Essential amino acid

As shown in Table 2, amino acids of pupae and adults of four pine caterpillars consisted of aspartic acid, threonine, serine, glutamic acid, proline, glycine, alanine, valine, methionine, isoleucine, leucine, tyrosine, phenylalanine, histidine, lysine, $\mathrm{NH}_{3}$, arginine, and tryptophan. Further, it showed that the pupae and adults of pine caterpillars are abundant of amino acids.

The importance of essential amino acids in the diet is emphasized in several studies $[25,26]$. The essential amino acids for human adult nutrition are isoleucine, lysine, methionine, phenylamine, threonine, tryptophan, valine and histidine [14]. Table 3 compares the essential amino acid contents of the caterpillars with the WHO/FAO/UNU pattern [26]. The table showed that most of the essential amino acids for human adult nutrition are higher than the levels WHO/FAO/UNU recommendations.

Table 3. Essential amino acids (mg/100g protein) of pine caterpillars against the WHO/FAO/UNU pattern.

\begin{tabular}{|c|c|c|c|c|c|c|c|}
\hline \multirow{2}{*}{ Amino acids } & \multirow{2}{*}{ WHO/FAO/UNU1985 } & \multicolumn{2}{|c|}{ D. houi } & \multicolumn{2}{|c|}{ D. punctatus Tehchangensis } & \multirow{2}{*}{$\begin{array}{l}\text { D. punctatus winshanensis } \\
\text { Pupae }\end{array}$} & \multirow{2}{*}{$\begin{array}{l}\text { D. kikuchii } \\
\text { Pupae }\end{array}$} \\
\hline & & Pupae & Adults & Pupae & Adults & & \\
\hline Lysine & 58 & 36.29 & 43.85 & 44.17 & 48.91 & 44.15 & 19.16 \\
\hline Leucine & 66 & 38.34 & 59.14 & 52.41 & 55.22 & 42.02 & 58.30 \\
\hline Isoleucine & 28 & 32.01 & 43.34 & 39.53 & 35.55 & 30.85 & 43.00 \\
\hline Methionine & 25 & 26.43 & 13.12 & 39.87 & 24.91 & 33.33 & 18.34 \\
\hline Valine & 35 & 35.73 & 55.48 & 40.38 & 41.15 & 32.30 & 66.65 \\
\hline Threonine & 34 & 30.34 & 31.56 & 34.71 & 35.73 & 31.74 & 41.17 \\
\hline Histidine & 19 & 19.73 & 29.57 & 22.51 & 21.66 & 20.21 & 46.47 \\
\hline Tryptophan & 11 & NA & NA & NA & NA & NA & NA \\
\hline
\end{tabular}

NA : Not attempted.

\section{Conclusion and Discussion}

\section{Conclusion}

The crude protein content of the pupae of the 4 species caterpillars ranged from $53.55 \%$ to $61.26 \%$, while the protein content of the adults of 2 species, D. punctatus techangensis and D. Houi, was $58.04 \%$ and $68.30 \%$ respectively. The fat and the energy content of pine caterpillars ranged respectively from $19.75 \%$ to $26.46 \%$ and from 406 to $473 \mathrm{kcal}$ per $100 \mathrm{~g}$ for the pupae; $6.56 \%$ to $24.63 \%$ and 327 to $454 \mathrm{kcal}$ per $100 \mathrm{~g}$ for the adults.

The amino acid composition of pupae and adults of four pine caterpillars are aspartic acid, threonine, serine, glutamic acid, proline, glycine, alanine, valine, methionine, isoleucine, leucine, tyrosine, phenylalanine, histidine, lysine, $\mathrm{NH}_{3}$, arginine, and tryptophan. In compared with the WHO/FAO/UNU pattern, most of the essential amino acids for human adult nutrition are higher than the levels as 
recommended by WHO/FAO/UNU.

Discussion

This study constitutes one part of IPM for pine caterpillars in China. Pine caterpillars are the important forest pests in China. In the past, much attention has been paid to mitigate damage and reduce the loss caused by them. However, the practice of consuming these insects by local ethnic people in Yunnan has long been ignored. Yet, in recent years we discovered this tradition and decided to do some research to encourage local and other people to consume or utilize these pests. In one hand, mass harvesting the pine caterpillars may reduce the use of pesticides considerably, and in the other hand, it may provide the indigenous people with high quality protein food.

The results show that the pine caterpillars can provide high quality proteins and high fat as well as caloric values. So from now on we should study these forest pests in terms of resource insects and try to turn them into good protein source.

\section{Acknowledgments}

This study was funded by the Special Public Welfare of Chinese Forestry Industry Research (no. 201204602), National Science and Technology plan (no.2012BAD19B08), and the Special Funds of Basic Scientific Research Cost of Central Public Welfare Scientific Research Institutes (no. RIRICAF201005M).

\section{References}

[1] AKINNAWO O. O., ABATAN M. O AND KETIKU A. O. [2002]: Toxicological study on the edible larva of cirina forda, (Westwood). African Journal of Biomedical. Research. (5):43 46.

[2] AOAC. [1995] Official methods of analysis $16^{\text {th }}$ ed. Association of Official Analytical Chemists, Arlington VA, USA.

[3] ASHIRU, M. O. [1988]: The Food value of the larva of Anaphe Venata Butler (Lepidoptera: Notodontdae) Ecol. Food Nutr. 22:313 320.

[4] CHEN CANJE [1990]: Integrated Management of Pine Caterpillars in China. Forestry Press of China, Beijing.

[5] CHEN SHAOJUN [1997]: The Analysis and evaluation of main nutrient component for Herse convolvuli. Acta Nutrimenta Sinica, 19 (1):114 117.

[6] DE FOLIART G. R. [1992]: Insects as human food. Crop Protection 11:395 399.

[7] DEFOLIART G. R. [1996]: An Overview of the role of edible insects in preserving biodiversity. Ecology of Food and Nutrition. 36: 109 132.

[8] DEFOLIART, G. R. [1989]: The Human Used of Insects as food and feed. Bull. EntomolSoc. Am. 35:22 35.

[9] DEFOLIART, G. R. [1995]: Edible insects as minilivestock. Biodiversity and Conservation 4, 306 321.
[10] ENE T. C [1963]: Insects and man in West Africa, Ibadan University Press, Ibadan.

[11] GULLAN P. J. AND CRANSTON P. S. [2004]: The insects, an outline of entomology. Blackwell publishing.

[12] HOU TAOQIAN. [1987]: Pine caterpillars in China. Science Press, Bejing.

[13] KOK. R. [1983]: The production of Insects for human food. Can. Inst. Food Sci. technol. J. 6 (1)5 18.

[14] LADRON DE GUEVARA O, PADILLA. P. [1995]: Amino acid determination in some edible Mexican insects. Amino Acids. 9:161 173.

[15] LI SHUO [2016]: A Review on Several Control Approaches for Dendrolimi in China. The Journal of Hebei Forestry Science and Technology, (3):76 79.

[16] MEYER-ROCHOW RVB [1973]: Edible insects in the three different ethnic groups of Papua and New Guinea. Am J Clin Nutr 26:663 667.

[17] PETERS T. M [1988]: Insects and human society. Van Nostrand Reinhold Press, USA.

[18] RAMOS-ELORDUY J [1997]: Insects: A Sustainable Source of Food? Ecology of Food and Nutrition Vol. 36:247 276.

[19] RAMOS-ELORDUY J, JOSE M [2002]: Edible insects of Chiapas, Mexico. Ecology of Food and Nutrition, 41:271 299.

[20] RAMOS-ELORDUY J., PINO M. J. M [1997]: Nutritional value of edible insects from the state of Oaxaca, Mexico. Journal of Food Composition and Analysis 10, 142 157.

[21] RYAN J. K.; JELEN P [1983]: Alkaline extraction of protein from spent honey bees. Journal of Food Science. 48:886 888.

[22] VAN HUIS A [2003]: Insects as food in Sub-Saharan Africa, Insect Sci. Applic. 23 (3)165 185.

[23] WEN LI ZHANG [1997]: Edibleentomology principle and application. Hunan Science and Technology press. Hunan.

[24] WHO/FAO [1973]: Report: energy and protein requirements: WHO Technical Report Series No. 724, Geneva.

[25] WHO/FAO [1965]: Report: energy and protein requirements. WHO Technical Report Series No. 522, Geneva.

[26] WHO/FAO/UNU [1985]: Report: energy and protein requirements: WHO Technical Report Series No. 724, Geneva.

[27] YANG CHEN [2015]: Occurrence Rule of Yunnan Pine Moth in Changning Xigui Forest Region and Its Control Methods. Forest Inventory and Planning. 40 (3):48 50.

[28] YANG TI, ZHOU CHONGZHAO [1993]: Comprehensive utilization of the silkworm pupae. Food Science 12:31 33.

[29] ZHANG SUFANG [2015]: Volatile Characters of Masson Pine Needles from Dendrolimus punctatus Frequent Outbreak Area, Occasional Outbreak Area, and Non-Outbreak Area. Scientia Silvae Sinicae, 51 (3):170 174.

[30] ZHU ZHU, BAO YANMEI [1995]: Production of fluid protein food by the silkworm pupae. Food Science, 16 (7) 45 47. 